\title{
Nucleosides 10: Synthesis of New Derivatives of Pyrimidine and Fused Pyrimidine Nucleosides of Expected Biological Activity
}

\author{
Laila M. Break1, Mosselhi A. M. Mohamed ${ }^{1,2}{ }^{*}$, Ohoud A. A. Al-Thubaiti1, Fatma E. M. Eibaih ${ }^{3}$ \\ ${ }^{1}$ Department of Chemistry, Faculty of Science, Taif University, Al-Haweiah, Taif, KSA \\ ${ }^{2}$ Department of Chemistry, Faculty of Science, Cairo University, Giza, Egypt \\ ${ }^{3}$ Department of Chemistry, Faculty of Science, King Saud University, Riyadh, KSA \\ Email: *mosselhimohamed@yahoo.com
}

How to cite this paper: Break, L.M., Mohamed, M.A.M., Al-Thubaiti, O.A.A. and Eibaih, F.E.M. (2019) Nucleosides 10: Synthesis of New Derivatives of Pyrimidine and Fused Pyrimidine Nucleosides of Expected Biological Activity. International Journal of Organic Chemistry, 9, 107-120. https://doi.org/10.4236/ijoc.2019.93010

Received: May 23, 2019

Accepted: July 8, 2019

Published: July 11, 2019

Copyright (c) 2019 by author(s) and Scientific Research Publishing Inc. This work is licensed under the Creative Commons Attribution International License (CC BY 4.0).

http://creativecommons.org/licenses/by/4.0/

\begin{abstract}
Pyrimidines, such as 6-amino-2-thio and 2-methylthiouracils and fused pyrimidines, such as thienopyrimidines reacted with $1-O$-acetyl-2,3,5-tri- $O$ benzoyl- $\beta$-D-ribofuranose to get new derivatives of the corresponding nucleosides. The obtained protected nucleosides were deprotected by methanolic sodium methoxide to get the corresponding free uracil and thienopyrimidine nucleosides. The new nucleosides formed were tested for biological activity against some of microorganism (some fungi and bacteria species). Some of the tested products showed moderate activity and the results were reported.
\end{abstract}

\section{Keywords}

Synthesis, Nucleosides, Pyrimidines, Fused Pyrimidines Heterocycles, Biological Activity

\section{Introduction}

Pyrimidines and their fused derivatives form the heterocyclic core of nucleic acid bases. These ring systems are incorporated into drugs used for AIDS, cancer and anti-viral treatment. The discovery of the anti-HIV activity in AZT containing the pyrimidine nucleus has stimulated a renewed interest in these molecules and has prompted the researcher to focus work on the synthesis and study of biological properties of newer series of pyrimidine derivatives [1] [2].

Various fused pyrimidines like purines, pteridines, quinazolines, pyridopyrimidines, triazolopyrimidines, pyrazolopyrimidines, pyrimidoazepines, fluoropyrimidines and pyrrolopyrimidines were studied in the past decade and were 
found to possess remarkable pharmacological properties [3]. Many pyrimidine nucleosides and analogues have been synthesized and studied for anticancer behaviour, and two are in general clinical use. A number of nucleosides were applied for remediation of breast cancer, gastrointestinal tract tumours in addition to other solid tumours [4]. Nucleosides bearing pyranosyl rings have been evaluated for their potential antiviral [5] [6], antioxidant [7] and antibiotic [8] properties and as building blocks in nucleic acid synthesis [9] (Figure 1).

Up-to-date synthetic strategies of the acyclic and cyclic pyridinethione nucleosides including their aza- and deaza-analogs have been exploited and highlighted throughout a review in 2019 [10].

For these biological and medicinal purposes and others, it is important to develop the field of the synthesis of nucleosides. As a part our research program dealing with the chemistry of azoles and azines nucleosides [11]-[20], and in continuation of this work, it was considered worthwhile to study the coupling reaction of pyrimidines, and fused pyrimidines with 1-O-acetyl-2,3,5-tri- $O$ benzoyl- $\beta$-D-ribofuranose to get new derivatives of the corresponding nucleosides with the attempt to discover some potential compounds of medicinal importance. Furthermore, the biological activities of the new prepared nucleosides were tested using some of microorganisms.

\section{Material and Methods}

\subsection{Chemistry}

All evaporations were carried out under reduced pressure at $60^{\circ} \mathrm{C}$. TLC was carried out on aluminum sheet silica gel 60 (Fluka) and detected by UV light. All melting points were measured on an electro-thermal melting point apparatus and are uncorrected. The ${ }^{1} \mathrm{H}$ and ${ }^{13} \mathrm{C}$ NMR spectra were recorded in deuterochloroform $\left(\mathrm{CDCl}_{3}\right)$ and deuterated dimethyl sulphoxide (DMSO- $\left.d_{6}\right)$ at $300 \mathrm{MHz}$ on a Varian Mercury VXR-300 NMR spectrometer (Cairo University) and at 600

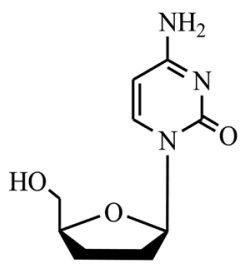

Zalcitabine

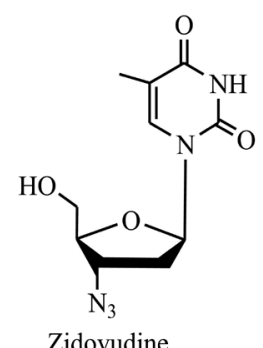

Zidovudine

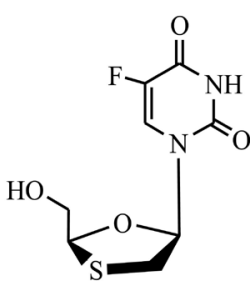

Emtricitabine<smiles>Cc1cn(C2CC3COC2O3)c(=O)[nH]c1=O</smiles>

Stavudine

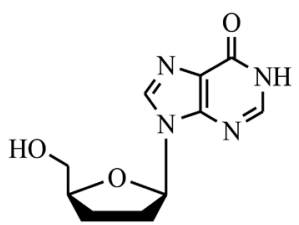

Didanosine<smiles>Nc1nc(NC2CC2)nc2c1ncn2C1CC2CC1O2</smiles>

Abacavir

Figure 1. Structure of commonly used nucleoside drugs. 
$\mathrm{MHz}$ on Bruker NMR spectrometer (King Abdelaziz University). Chemical shifts were related to that of the solvent. Biological activity was carried out at the Microanalytical Center of Cairo University, Cairo, Egypt. Mass spectra were recorded on a Shimadzu GC MS-QP 1000 EX mass spectrometer at $70 \mathrm{eV}$. Elemental analyses were carried out at the Microanalytical Center of Cairo University, Giza, Egypt.

Synthesis of 6-amino-2-methylthiouracil (1b) [21]:

To a solution of 6-amino-2-thiouracil (1a) [22] (1.43 g, $10 \mathrm{mmol}$ ) in DMF (20 $\mathrm{ml})$, potassium carbonate $(1.4 \mathrm{~g}, 10 \mathrm{mmol})$ and methyl iodide $(1.42 \mathrm{~g}, 10 \mathrm{mmol})$ were added and stirred at room temperature for $3 \mathrm{~h}$. The reaction mixture was then diluted with cold water $(20 \mathrm{ml})$ and left in refrigerator overnight. The product was filtered, dried and then recrystallized from ethanol to give colorless crystals of $1 \mathrm{~b}$. Yield, $1.3 \mathrm{~g}\left(81.9 \%\right.$ ); m.p. $261^{\circ} \mathrm{C}-264^{\circ} \mathrm{C}$ (lit. m.p. $271^{\circ} \mathrm{C}-273^{\circ} \mathrm{C}$ [21]). ${ }^{1} \mathrm{H}$ NMR (DMSO, $\left.300 \mathrm{MHz}\right), \delta \mathrm{H}: 2.2\left(\mathrm{~s}, 3 \mathrm{H}, \mathrm{SCH}_{3}\right.$ ), 4.9 (s, $\left.1 \mathrm{H}, 5-\mathrm{CH}\right)$, $6.46\left(\mathrm{~s}, 2 \mathrm{H}, \mathrm{NH}_{2}\right), 11.5(\mathrm{~s}, 1 \mathrm{H}, \mathrm{NH})$.

General Procedure for the ribosylation of 6-amino-2-thio and 2-methylthiouracils (1a) \& (1b): Synthesis of 6-amino-1-(2,3,5-tri-O-benzoyl$\beta$-D-ribofuranosyl)-2-thio and 2-methylthiouracil (4a) \& (4b).

A mixture of 6-amino-2-thiouracil (1a) [22] or 6-amino-2-methylthiouracil (1b) [21] (10 mmol) and dry hexamethyldisilazane $(20 \mathrm{ml})$ was heated under reflux for $24 \mathrm{~h}$ with a catalytic amount of ammonium sulfate. After the solution has been cooled, it was evaporated to dryness under anhydrous condition to give the silylated derivative $\mathbf{2} \mathbf{a}$ or $\mathbf{2} \mathbf{b}$, which was directly dissolved in $(15 \mathrm{ml})$ of dry 1,2-dichloroethane. To this solution was added a solution of 1-O-acetyl-2,3,5-tri$O$-benzoyl- $\beta$-D-ribofuranose (3) $(4.8 \mathrm{~g}, 9.6 \mathrm{mmol})$ dissolved in dry 1,2-dichloroethane $(15 \mathrm{ml})$, and the mixture was treated with trimethylsilyltrifluoromethanesulfonate $(2.00 \mathrm{ml}, 10 \mathrm{mmol})$ as catalyst. After the solution had been stirred for $24 \mathrm{~h}$ (TLC) at room temperature, it was diluted with chloroform (30 ml), washed with a saturated solution of aqueous sodium bicarbonate $(100 \mathrm{ml})$, water $(3 \times 20 \mathrm{ml})$ and dried over anhydrous sodium sulfate. Separation of the pure product was achieved by silica gel column chromatography with chloroform and ethyl acetate (9:1). The evaporation of the main fraction $\mathbf{4 a}$ or $\mathbf{4 b}$, respectively was obtained as a colorless solid.

4a: Yield 2.6 g, (52\%); m.p. $144^{\circ} \mathrm{C}$; ${ }^{1} \mathrm{H}$ NMR $\left(\mathrm{CDCl}_{3}, 600 \mathrm{MHz}\right), \delta \mathrm{H}: 4.7-4-9$ (m, 4H, 5-CH, 4'H \& 5'H), 5.6 - 5.6 (m, H, 3'H), 5.7 - 5.8 (m, H, 2' H), 5.9 (d, 1H, $\left.1^{\prime} \mathrm{H}, J_{1^{\prime}, 2^{\prime}}=4.0 \mathrm{~Hz}\right), 6.6\left(\mathrm{~s}, 2 \mathrm{H}, \mathrm{NH}_{2}\right), 7.26-8.0(\mathrm{~m}, 15 \mathrm{H}, 3 \mathrm{Ph}), 10.8(\mathrm{~s}, 1 \mathrm{H}, \mathrm{NH})$; ${ }^{13} \mathrm{C}$ NMR $\left(\mathrm{CDCl}_{3}, 150 \mathrm{MHz}\right), \delta \mathrm{C}: 64.1,65.1,72.3,76.1,77.2,79.4,79.7,95.9,100$. 5, 128.4 - 133.6, 165.2, 165.5, 166.4, $173.6(\mathrm{C}=\mathrm{S})$; MS: $m / z=587$ (41\%). Anal. calcd. for $\mathrm{C}_{30} \mathrm{H}_{25} \mathrm{~N}_{3} \mathrm{O}_{8} \mathrm{~S}$ (587.6); C, 61.32; H, 4.29; N, 7.15; S, 5.46. Found, C, 61.10; H, 4.00; N, 6.80\%.

4b: Yield 2.5 g, (41\%); m.p. $142{ }^{\circ} \mathrm{C} ;{ }^{1} \mathrm{H}$ NMR $\left(\mathrm{CDCl}_{3}, 600 \mathrm{MHz}\right), \delta \mathrm{H}: 2.3$ (s, $\left.3 \mathrm{H}, \mathrm{SCH}_{3}\right), 4.6$ - $4.8\left(\mathrm{~m}, 4 \mathrm{H}, 5-\mathrm{CH}, 4^{\prime} \mathrm{H} \& 5^{\prime} \mathrm{H}\right), 5.5$ - $5.6\left(\mathrm{~m}, \mathrm{H}, 3^{\prime} \mathrm{H}\right), 5.7$ - $5.8(\mathrm{~m}$, $\left.\mathrm{H}, 2^{\prime} \mathrm{H}\right), 6.0\left(\mathrm{~d}, 1 \mathrm{H}, 1^{\prime} \mathrm{H}, J_{1^{\prime}, 2^{\prime}}=4.0 \mathrm{~Hz}\right), 6.5\left(\mathrm{~s}, 2 \mathrm{H}, \mathrm{NH}_{2}\right), 7.2-8.0(\mathrm{~m}, 15 \mathrm{H}, 3 \mathrm{Ph})$, $10.5(\mathrm{~s}, 1 \mathrm{H}, \mathrm{NH}) ;{ }^{13} \mathrm{C} \mathrm{NMR}\left(\mathrm{CDCl}_{3}, 150 \mathrm{MHz}\right), \delta \mathrm{C}: 15.0,62.9,65.0,71.5,72.0$, 
76.5, 79.9, 95.0, 101.0, 128.0 - 133.5, 165.2, 166.0, 172.5 (C=S); MS: $m / z=601$ (35\%). Anal. calcd. For $\mathrm{C}_{31} \mathrm{H}_{27} \mathrm{~N}_{3} \mathrm{O}_{8} \mathrm{~S}$ (601.63); C, 61.89; H, 4.52; N, 6.98; S, 5.33. Found, C, 61.10; H, 4.00; N, 6.80\%.

General Procedure for the deprotection of 6-amino-1-(2,3,5-tri-O-benzoyl$\beta$-D-ribofuranosyl)-2-thio and 2-methylthiouracil (4a) \& (4b): Synthesis of 6-amino-1-( $\beta$-D-ribofuranosyl)-2-thio and 2-methylthiouracil (5a) \& (5b).

A mixture of the protected nucleoside $(1.0 \mathrm{mmol}) 4 \mathrm{a}$ or $4 \mathrm{~b}$, absolute methanol $(30 \mathrm{ml})$ and sodium methoxide $(0.06 \mathrm{~g}, 1.1 \mathrm{mmol})$, was stirred at room temperature for $24 \mathrm{~h}$ (TLC). The solvent was evaporated under vacuum and the residue was dissolved in hot water and neutralized with acetic acid. The precipitate formed was filtered, dried and crystallized from water to afford $\mathbf{5} \mathbf{a}$ or $\mathbf{5} \mathbf{b}$, respectively as colorless crystals.

5a: Yield, $135 \mathrm{mg}$, (49\%); m.p259 ${ }^{\circ}$; ${ }^{1} \mathrm{H}$ NMR (DMSO- $d_{6}, 300 \mathrm{MHz}$ ), $\delta \mathrm{H}: 3.4$ (m, 2H, 5', 5'H), $3.80\left(\mathrm{~m}, 1 \mathrm{H}, 4^{\prime} \mathrm{H}\right), 4.10-4.2\left(\mathrm{~m}, 2 \mathrm{H}, 2^{\prime} \mathrm{H} \& 3^{\prime} \mathrm{H}\right), 4.7$ (s, 1H, 5-CH), 5.0 (t, 1H, 5'-OH), 5.3 (d, J=4.0 Hz, 1'-H), 5.5 (d, J=4 Hz, 3'-OH), 6.1 $\left(\mathrm{d}, J=4.0 \mathrm{~Hz}, 1 \mathrm{H}, 2^{\prime}-\mathrm{OH}\right), 8.45$ (s, $\left.1 \mathrm{H}, \mathrm{NH}\right) ; \mathrm{MS}: m / z=275$ (65\%). Anal. calcd. For $\mathrm{C}_{9} \mathrm{H}_{13} \mathrm{~N}_{3} \mathrm{O}_{5} \mathrm{~S}$ (275.28); C, 39.27; H, 4.76; N, 15.26; S, 11.65. Found, C, 39.10; H, 5.00; N, 15.00; S, 11.5\%.

5b: Yield, $160 \mathrm{mg}$, (55\%); m.p 223 ${ }^{\circ} \mathrm{C} ;{ }^{1} \mathrm{H}$ NMR (DMSO- $d_{6}, 300 \mathrm{MHz}$ ), $\delta \mathrm{H}: 2.2$ (s, $\left.3 \mathrm{H}, \mathrm{SCH}_{3}\right), 3.5\left(\mathrm{~m}, 2 \mathrm{H}, 5^{\prime}, 5^{\prime \prime} \mathrm{H}\right), 3.80\left(\mathrm{~m}, 1 \mathrm{H}, 4^{\prime} \mathrm{H}\right), 4.0-4.1(\mathrm{~m}, 2 \mathrm{H}, 2 \mathrm{H}$ \& 3'H), 4.8 (s, 1H, 5-CH), 5.1 (t, 1H, 5'-OH), 5.4 (d, J=4.0 Hz, 1'- H), 5.5 (d, J= 4 $\left.\mathrm{Hz}, 3^{\prime}-\mathrm{OH}\right), 6.0$ (d, $\left.J=3.8 \mathrm{~Hz}, 1 \mathrm{H}, 2^{\prime}-\mathrm{OH}\right)$; MS: $m / z=289$ (45\%). Anal. calcd. for $\mathrm{C}_{10} \mathrm{H}_{15} \mathrm{~N}_{3} \mathrm{O}_{5} \mathrm{~S}$ (289.31); C, 41.52; H, 5.23; N, 14.52; S, 11.08. Found, C, 41.80; H, $5.10 ; \mathrm{N}, 14.40 ; \mathrm{S}, 11.00 \%$.

Ribosylation of 6-amino-1-benzyl-2-thiouracil (8): Synthesis of 6-amino3-(2,3,5-tri-O-benzoyl- $\beta$-D-ribofuranosyl)-1-benzyl-2-thiouracil (9).

A mixture of 6-amino-1-benzyl-2-thiouracil (8) $(2.33 \mathrm{~g}, 10 \mathrm{mmol})$ and dry hexamethyldisilazane $(60 \mathrm{ml})$ was heated under reflux for $24 \mathrm{~h}$ with a catalytic amount of ammonium sulfate. After the solution cooled, it was evaporated to dryness under anhydrous condition and the residue was dissolved in $(20 \mathrm{ml})$ of dry 1,2-dichloroethane. To this solution was added a solution of 1-O-acety1-2,35 -tri- $O$-benzoyl- $\beta$-D-ribofuranose (3) (4.8 g, $9.80 \mathrm{mmol})$ dissolved in dry 1,2-dichloroethane $(20 \mathrm{ml})$, and the mixture was treated with $(2 \mathrm{ml}, 10 \mathrm{mmol})$ trimethylsilyl trifluoromethanesulfonate in dry 1,2-dichloroethane $(10 \mathrm{ml})$ as catalyst was added dropwise. After the solution had been stirred for $24 \mathrm{~h}$ at room temperature (TLC), it was diluted with chloroform $(20 \mathrm{ml})$, washed with a saturated solution of aqueous sodium bicarbonate $(100 \mathrm{ml})$, water $(3 \times 20 \mathrm{ml})$ and dried over anhydrous sodium sulfate. Separation of the pure product was achieved by silica gel column chromatography with a chloroform: ethyl acetate (9:1). On evaporation of the main fraction, protected nucleoside 9 as buff crystals.

Yield 2.98 g, (40\%); m.p. $179^{\circ} \mathrm{C}$; ${ }^{1} \mathrm{H}$ NMR $\left(\mathrm{CDCl}_{3}, 300 \mathrm{MHz}\right), \delta \mathrm{H}: 4.6$ - 4.9 (m, $\left.4 \mathrm{H}, 5-\mathrm{CH}, 4^{\prime} \mathrm{H} \& 5^{\prime} \mathrm{H}\right), 5.2\left(\mathrm{~s}, 2 \mathrm{H}, \mathrm{CH}_{2}\right), 5.3-5.5\left(\mathrm{~m}, 2 \mathrm{H}, 2^{\prime} \mathrm{H} \& 3^{\prime} \mathrm{H}\right), 6.2(\mathrm{~d}, 1 \mathrm{H}$, $\left.1^{\prime} \mathrm{H}, J_{1^{\prime}, 2^{\prime}}=4.0 \mathrm{~Hz}\right), 6.5\left(\mathrm{~s}, 2 \mathrm{H}, \mathrm{NH}_{2}\right), 7.15-8.1(\mathrm{~m}, 20 \mathrm{H}, 4 \mathrm{Ph}) ;{ }^{13} \mathrm{C} \mathrm{NMR}\left(\mathrm{CDCl}_{3}\right.$, 
$75 \mathrm{MHz}), \delta \mathrm{C}: 43,104.5,127.0$ - 132.9, 135.0, 138.1, 166.2 167.4, $173.0(\mathrm{C}=\mathrm{S}) ; \mathrm{MS}:$ $m / z=677\left(\mathrm{M}^{+}, 20 \%\right)$. Anal. calcd. for $\mathrm{C}_{37} \mathrm{H}_{31} \mathrm{~N}_{3} \mathrm{O}_{8} \mathrm{~S}(677.72) ; \mathrm{C}, 65.57 ; \mathrm{H}, 4.61 ; \mathrm{N}$, 6.20; S, 4.73. Found, C, 65.30; H, 4.30, N, 6.10; S, 4.50\%.

Deprotection of 6-amino-3-(2,3,5-tri-O-benzoyl- $\beta$-D-ribofuranosyl)-1benzyl-2-thiouracil (9): Synthesis of 6-amino-3-( $\beta$-D-ribofuranosyl)-1-benzyl2-thiouracil (10).

A mixture of compound $9(200 \mathrm{mg}, 0.27 \mathrm{mmol})$ in absolute methanol $(10 \mathrm{ml})$ and sodium methoxide $(16.04 \mathrm{mg}, 0.29 \mathrm{mmol})$ was stirred at room temperature for $24 \mathrm{~h}$ [TLC (chloroform/Ethyl Acetate) (9:1)]. Evaporation of the solvent under vacuum gave a white solid, which was dissolved in hot water and neutralized with acetic acid. The precipitate formed was filtered and dried to give pale yellow crystals of 10 .

Yield, $100 \mathrm{mg}$, (90\%); m.p $280{ }^{\circ} \mathrm{C} .{ }^{1} \mathrm{H}$ NMR (DMSO- $d_{6}, 300 \mathrm{MHz}$ ); $\delta \mathrm{H}: 4.0-$ $4.2\left(\mathrm{~m}, 3 \mathrm{H}, 5^{\prime}, 5^{\prime \prime} \mathrm{H} \& 4^{\prime} \mathrm{H}\right), 4.5-4.6\left(\mathrm{~m}, 2 \mathrm{H}, 5-\mathrm{CH} \& 4^{\prime} \mathrm{H}\right), 5.2-5.5\left(\mathrm{~m}, 4 \mathrm{H}, \mathrm{CH}_{2}\right.$, 3'H \& 2'H), 5.8 - 5.9 (m, 2H, 5'-OH \& 3'OH), 6.0 (m, 1H, 2'-OH), 6.3 (d, $J=4$ $\left.\mathrm{Hz}, 1 \mathrm{H}, 1^{\prime}-\mathrm{H}\right), 6.55$ (s, 2H, $\mathrm{NH}_{2}$ ), $7.25-8.2$ (m, 5H, Ph); MS: $m / z=365$ (37\%). Anal. calcd. for $\mathrm{C}_{16} \mathrm{H}_{19} \mathrm{~N}_{3} \mathrm{O}_{5} \mathrm{~S}$ (365.41); C, 52.59; H, 5.24; N, 11.50; S, 8.78. Found, C, 52.50; H, 5.50, N, 11.30; S, 8.60\%.

General Procedure for the ribosylation of 5,6-dimethylthieno[2, 3-d]pyrimidin-4-one (12a) and 5,6,7,8-tetrahydro-3H-benzo[4,5]thieno[2, 3-d]pyrimidin-4-one (12b): Synthesis of 1-(2,3,5-tri-O-benzoyl- $\beta$-D-ribofuranosyl)-5,6dimethylthieno[2,3-d]pyrimidin-4-one(13a) and 1-(2,3,5-triO-benzoyl- $\beta$-D-ribofuranosyl)-5,6,7,8-tetrahydro-3H-benzo[4,5] thieno[2,3d]pyrimidin-4-one (13b).

A mixture of 5,6-dimethylthieno[2,3-d]pyrimidin-4-one (12a) or 5,6,7,8-tetrahydro-3H-benzo[4,5]thieno[2,3-d]pyrimidin-4-one (12b) $(10 \mathrm{mmol})$ and dry hexamethyldisilazane $(30 \mathrm{ml})$ was heated under reflux $24 \mathrm{~h}$ with a catalytic amount of ammonium sulfate. After the solution was cooled, it was evaporated to dryness under anhydrous condition to give the silylated derivative, which was dissolved in $(20 \mathrm{ml})$ of dry 1,2-dichloroethane. To this solution was added a solution of 1- $O$-acetyl-2,3,5-tri- $O$-benzoyl- $\beta$-D-ribofuranose (3) (4.6 g, $9.2 \mathrm{mmol}$ ) dissolved in dry 1,2-dichloroethane $(10 \mathrm{ml})$ and the mixture was treated with trimethylsilyl trifluoromethanesulfonate $(2.00 \mathrm{ml}, 10 \mathrm{mmol})$ as a catalyst. After the solution had been stirred for $24 \mathrm{~h}$ at room temperature (TLC), it was diluted with chloroform $(40 \mathrm{ml})$, washed with a saturated solution of aqueous sodium bicarbonate $(100 \mathrm{ml})$ and water $(3 \times 20 \mathrm{ml})$ and dried over anhydrous sodium sulfate. Separation of the pure product was achieved by silica gel column chromatography with chloroform and ethyl acetate (9:1). On the evaporation of the main fraction, $13 \mathrm{a}$ or $\mathbf{1 3 b}$, respectively as pale yellow crystals was obtained and recrystallized from ethanol.

13a: Yield, $2.5 \mathrm{~g}$ (40\%); mp $111^{\circ} \mathrm{C} ;{ }^{1} \mathrm{H} \mathrm{NMR}\left(\mathrm{CDCl}_{3}, 600 \mathrm{MHz}\right), \delta \mathrm{H} 2.54$ (s, $\left.3 \mathrm{H}, \mathrm{CH}_{3}\right), 2.60\left(\mathrm{~s}, 3 \mathrm{H}, \mathrm{CH}_{3}\right), 4.5-4.9\left(\mathrm{~m}, 3 \mathrm{H}, 4^{\prime} \mathrm{H} \& 5^{\prime} \mathrm{H}\right), 5.4(\mathrm{~m}, \mathrm{H}, 3 \mathrm{H}), 5.8(\mathrm{~m}$, $\left.\mathrm{H}, 2^{\prime} \mathrm{H}\right), 6.4-6.5\left(\mathrm{~d}, 1 \mathrm{H}, 1^{\prime} \mathrm{H}, J_{1^{\prime}, 2^{\prime}}=5.0 \mathrm{~Hz}\right), 7.2-8.2(\mathrm{~m}, 16 \mathrm{H}, \mathrm{CH} \& 3 \mathrm{Ph}),{ }^{13} \mathrm{C}$ NMR $\left(\mathrm{CDCl}_{3}, 150 \mathrm{MHz}\right), \delta \mathrm{C}: 13.5,20.5,63.7,75.5,77.3,80.8,86.2,95.9,100.1$, 
102.5, 123.2 - 134.1, 142.3, 157.5, 159.3, 163.3, 163.5, 165.5, 169.0. Anal. calcd. for $\mathrm{C}_{34} \mathrm{H}_{28} \mathrm{~N}_{2} \mathrm{O}_{8} \mathrm{~S}$ (624.66); C, 65.37; H, 4.52; N, 4.48; S, 5.13. Found, C, 65.60; $\mathrm{H}$, $4.50 ; \mathrm{N}, 4.20 ; \mathrm{S}, 5.10 \%$.

13b: Yield, $2.8 \mathrm{~g}$ (43\%); mp $129^{\circ} \mathrm{C} ;{ }^{1} \mathrm{H}$ NMR $\left(\mathrm{CDCl}_{3}, 600 \mathrm{MHz}\right), \delta \mathrm{H} 1.80(\mathrm{~m}$, $\left.2 \mathrm{H}, \mathrm{CH}_{2}\right), 2.35\left(\mathrm{~m}, 4 \mathrm{H}, 2 \mathrm{CH}_{2}\right), 3.0\left(\mathrm{t}, 2 \mathrm{H}, \mathrm{CH}_{2}, J=7.1 \mathrm{~Hz}\right), 4.25-4.8\left(\mathrm{~m}, 3 \mathrm{H}, 4^{\prime}\right.$ $\left.\mathrm{H} \& 5^{\prime} \mathrm{H}\right), 5.20\left(\mathrm{t}, 1 \mathrm{H}, \mathrm{H}-3^{\prime}, J=5.0 \mathrm{~Hz}\right), 5.50\left(\mathrm{t}, 1 \mathrm{H}, \mathrm{H}-2^{\prime}, J=5.0 \mathrm{~Hz}\right), 6.4(\mathrm{~d}, 1 \mathrm{H}$, $\left.\mathrm{H}-1^{\prime}, J_{1^{\prime}, 2^{\prime}}=5.1 \mathrm{~Hz}\right), 7.3-8.2(\mathrm{~m}, 16 \mathrm{H}, \mathrm{CH} \& 3 \mathrm{Ph}) ;{ }^{13} \mathrm{C} \mathrm{NMR}\left(\mathrm{CDCl}_{3}, 150 \mathrm{MHz}\right)$, $\delta$ C: $21.0,21.5,21.7,22.0,27.0,27.5,27.7,29.0,30.0$, 33.0, 62.0, 68.0, 69.0, 74.1, $82.5,120.0,136.4,137.0,152.0,158.5,159.8,168.0,169.0,169.5$. Anal. calcd. for $\mathrm{C}_{36} \mathrm{H}_{30} \mathrm{~N}_{2} \mathrm{SO}_{8}$ (650.7); C, 66.45; H, 4.65; N, 4.31; S, 4.93. Found, C, 66.30; H, 4.10; N, 4.10; S, 4.60\%.

General Procedure for the deprotection of $13 \mathrm{a}$ and 13b: Synthesis of1-( $\beta$-D-ribofuranosyl)-5,6-dimethylthieno[2,3-d]pyrimidin-4-one (14a) and 1 -( $\beta$-D-ribofuranosyl)-5,6,7,8-tetrahydro-3H-benzo[4,5]thieno[2,3-d]pyrimidin4-one (14b).

A mixture of the protected nucleoside $13 \mathrm{a}$ or $13(2 \mathrm{mmol})$, absolute methanol $(40 \mathrm{ml})$, and sodium methoxide $(0.18 \mathrm{~g}, 2.1 \mathrm{mmol})$, was stirred at room temperature for $24 \mathrm{~h}$ (TLC). The solvent was evaporated under vacuum and the residue was dissolved in hot water and neutralized with acetic acid. The precipitate formed was filtered, dried and recrystallized from water to give pure pale yellow powder of $14 \mathrm{a}$ or $14 \mathrm{~b}$, respectively.

14a: Yield, $0.27 \mathrm{~g}(44 \%) ; \mathrm{mp} 191^{\circ} \mathrm{C}-193^{\circ} \mathrm{C} ;{ }^{1} \mathrm{H}$ NMR $\left(\mathrm{CD}_{3} \mathrm{OD}, 600 \mathrm{MHz}\right), \delta \mathrm{H}$ 2.5 (s, 3H, $\left.\mathrm{CH}_{3}\right), 2.55$ (s, 3H, $\mathrm{CH}_{3}$ ), $3.70-3.85$ (m, 2H, H-5'), 4.00 (m, 1H, H-4'), 4.20 (m, 1H, H-3'), $4.35-4.40\left(\mathrm{~m}, 1 \mathrm{H}, \mathrm{H}-2^{\prime}\right), 4.7-4.8$ (t, 1H, OH-5', $\left.J=5 \mathrm{~Hz}\right)$, $5.1-5.2\left(\mathrm{~d}, 1 \mathrm{H}, \mathrm{OH}-3^{\prime}, J=5 \mathrm{~Hz}\right), 5.4-5.5\left(\mathrm{~d}, 1 \mathrm{H}, \mathrm{OH}-2^{\prime}, J=5 \mathrm{~Hz}\right), 6.1-6.2(\mathrm{~d}$, $\left.1 \mathrm{H}, J_{1^{\prime}, 2^{\prime}}=5 \mathrm{~Hz}, \mathrm{H}-1^{\prime}\right), 7.2(\mathrm{~s}, 1 \mathrm{H}, \mathrm{CH}),{ }^{13} \mathrm{C} \mathrm{NMR}\left(\mathrm{CD}_{3} \mathrm{OD}\right), \delta \mathrm{C}: 14.5,20.5,63.0$, 75.0, 77.0, 80.1, 86.1, 95.9, 100.0, 123.2 - 134.0, 142.5, 159.3, 163.5, 165.5, 170.0 . Anal. calcd. for $\mathrm{C}_{13} \mathrm{H}_{16} \mathrm{~N}_{2} \mathrm{O}_{5} \mathrm{~S}$ (312.34); C, 49.99; H, 5.16; N,8.97; S, 10.27. Found, C, 49.80; H, 5.00; N, 8.90; S, 10.10\%.

14b: Yield, 0.25 g, 37\%; m. p. $158^{\circ} \mathrm{C}$; ${ }^{1} \mathrm{H}$ NMR (DMSO- $d_{6}, 600 \mathrm{MHz}$ ): $\delta \mathrm{H} 1.80$ (m, $2 \mathrm{H}, \mathrm{CH}_{2}$ ), $2.80\left(\mathrm{~m}, 4 \mathrm{H}, 2 \mathrm{CH}_{2}\right), 3.30$ (s, $\left.2 \mathrm{H}, \mathrm{CH}_{2}\right), 3.70-3.85$ (m, 2H, H-5'), $4.00\left(\mathrm{~m}, 1 \mathrm{H}, \mathrm{H}-4^{\prime}\right), 4.20\left(\mathrm{~m}, 1 \mathrm{H}, \mathrm{H}^{-} 3^{\prime}\right), 4.35-4.40\left(\mathrm{~m}, 1 \mathrm{H}, \mathrm{H}-2^{\prime}\right), 4.7-4.8(\mathrm{t}, 1 \mathrm{H}$, OH-5', $J=5 \mathrm{~Hz}), 5.1-5.2\left(\mathrm{~d}, 1 \mathrm{H}, \mathrm{OH}-3^{\prime}, J=5 \mathrm{~Hz}\right), 5.4-5.5\left(\mathrm{~d}, 1 \mathrm{H}, \mathrm{OH}-2^{\prime}, J=5\right.$ $\mathrm{Hz}), 6.1-6.2\left(\mathrm{~d}, 1 \mathrm{H}, J_{1^{\prime}, 2^{\prime}}=5 \mathrm{~Hz}, \mathrm{H}-1^{\prime}\right), 7.5(\mathrm{~s}, 1 \mathrm{H}, \mathrm{CH}) ;{ }^{13} \mathrm{C}$ NMR (DMSO- $d_{6}$ ): SC 22.0, 22.0, 24.1, 25.0, 61.5, 70.5, 75.5, 85.3, 87.5, 128.0, 129.0, 130.0, 132.0, 158.0, 165.0. Anal. Calcd. for $\mathrm{C}_{15} \mathrm{H}_{18} \mathrm{~N}_{2} \mathrm{O}_{5} \mathrm{~S}$ (338.379); C, 53.24; H, 5.36; N, 8.28; S, 9.48. Found, C, 53.20; H, 5.10; N, 8.00, S, 9.30\%.

\subsection{Antimicrobial Assay}

Cultures of two bacterial species namely, Escherichia coli EC, and Staphylococcus aureus SA as well as two fungal species, namely Aspergillus flavus AF, and Candida albicans CA were used to investigate the antimicrobial activity of ten products, namely, 4a,b; 5a,b; $9 ; 10 ; 13 \mathrm{a}, \mathrm{b}$ and $14 \mathrm{a}, \mathrm{b}$. The antimicrobial activity 
was assayed biologically using the diffusion plate technique. The latter technique was carried out by pouring a spore suspension of the fungal species $\left(1 \mathrm{~cm}^{3}\right.$ of sterile water contains approximately 108 conidia) or spreading bacterial suspension over a solidified malt agar medium. The layer is allowed to set for $30 \mathrm{~min}$. A solution of the test compounds $\left(1.0 \mathrm{~g}=\mathrm{cm}^{3}\right)$ in DMSO was placed onto sterile 5 $\mathrm{mm}$ filter paper discs and allowed to dry, then the discs were placed on the centre of the malt agar plate and incubated at optimum incubation temperature $28^{\circ} \mathrm{C} \pm 2^{\circ} \mathrm{C}$. The bactericide Ampicillin and the fungicide Amphotericin $\mathrm{B}$ were used as standards under the same conditions. Measurements were considered after $72 \mathrm{~h}$ for fungi and $24 \mathrm{~h}$ for bacteria. The results are summarized in Table 1.

\section{Results and Discussion}

\subsection{Chemistry}

The first required starting materials in (Scheme 1) were 6-amino-2-thio-(1a) and 2-methylthio-(1b) uracils which were prepared according to literature reported methods [21] [22]. Ribosylation of $1 \mathbf{a}$ and $1 \mathbf{b}$ with $1-O$-acetyl-2,3,5-tri- $O$ benzoyl- $\beta$-D-ribofuranose (3) was carried out by the silylation method according to Vorbruggen [23] by refluxing of $\mathbf{1 a}$ and $\mathbf{1 b}$ in hexamethyldisilazane (HMDS) with ammonium sulfate as a catalyst to get the silylated product $2 \mathrm{a}$ and $2 \mathrm{~b}$, respectively. Each of the silylated compounds $2 \mathrm{a}$ or $\mathbf{2 b}$ was stirred with the protected ribose 3 in dry 1,2-dichloroethane and trimethylsilane triflate; $\mathrm{CF}_{3} \mathrm{SO}_{2} \mathrm{OSiMe}_{3}$ as a catalyst at room temperature for 24 hours. This method yielded the benzoylated $N$-nucleosides, 6-amino-1-(2,3,5-tri- $O$-benzoyl- $\beta$-D-ribofuranosyl)-2-thio and 2-methylthiouracil (4a) or (4b), respectively (see Scheme 1), which hitherto have not been reported in literature yet.

The structure of the latter products (4a) or (4b) was established and confirmed on the bases of their elemental analyses and spectral data $\left({ }^{1} \mathrm{H} \&{ }^{13} \mathrm{C} \mathrm{NMR}\right.$ and MS) (see Experimental), which were consistent with the structure of nucleosides $4 \mathrm{a}$ and $\mathbf{4 b}$. Thus, the spectral data for $4 \mathrm{a}$ as an example, revealed in its ${ }^{1} \mathrm{H}$ NMR spectrum a doublet at $\delta=5.9$ assigned to the anomeric proton of the ribose moiety with a spin-spin coupling constant equal to $4.0 \mathrm{~Hz}$ that corresponds to a diaxial orientation for the 1'- and 2'-H protons, i.e., the $\beta$-configuration [1] [12]-[20]. ${ }^{13} \mathrm{C}$ NMR spectrum of $4 \mathrm{a}$ revealed $C$-ribose moiety at chemical shifts of $\delta 64.1,65.1,72.3,76.1,77.2,79.4,79.7,95.9,100.5$. Formation of $N$-nucleosides, 4 a and $4 \mathrm{~b}$ and not $S$-nucleosides I is based on that: 1) the formation of nucleoside (4b) is carried out from the starting material, 6-amino-2-methylthiouracil (1b), 2) ${ }^{13} \mathrm{C}$ NMR of $4 \mathrm{a}$ which revealed characteristic peak at $\delta 173.6$ for $\mathrm{C}=\mathrm{S}$ group. Thus a distinction between the $O$-, $N$-, and $S$-glycosides was possible by comparison of ${ }^{13} \mathrm{C}$ NMR spectra with those of literature data of similar compounds [24] [25] [26] [27] [28]. ${ }^{13} \mathrm{C} \mathrm{C}=\mathrm{S}$ Chemical shifts of $\delta 172.0$ were reported for cycloalkyl[4,5]thieno[2,3- $d]$ pyrimidin-4-one-2-thione, while 2-alkylthiocycloalkyl$[4,5]$ thieno $[2,3-d]$ pyrimidin-4-one showed chemical shifts of C-2 (C-SR) around 


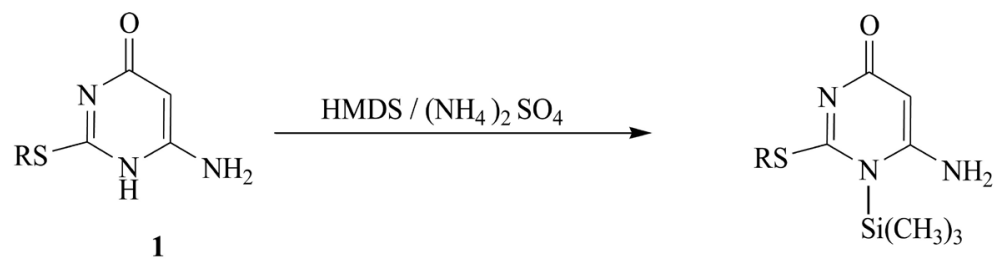

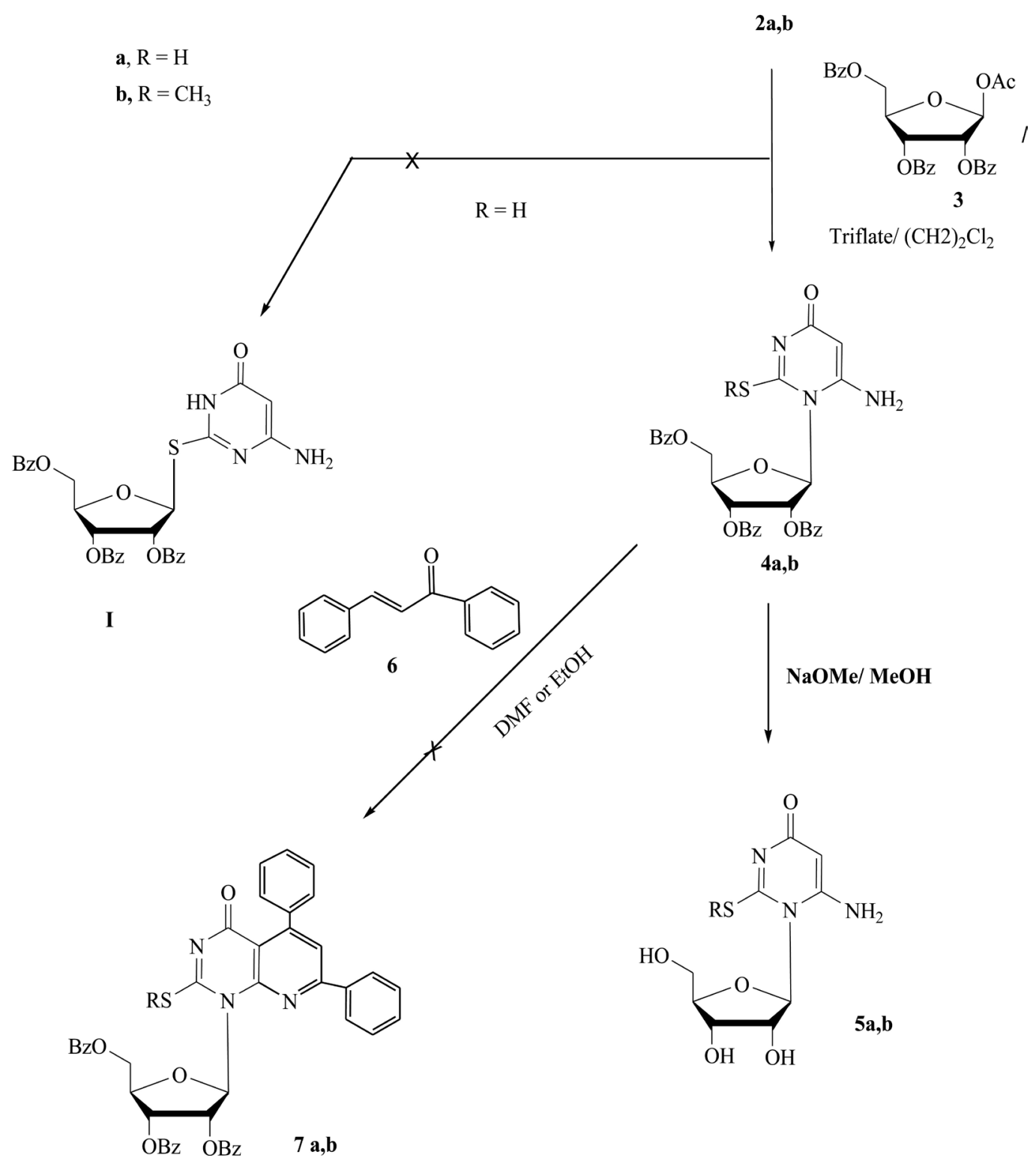

Scheme 1. Ribosylation of 6-amino-2-thio and 2-methylthiouracils.

$\delta$ 159. Deprotection of the protected nucleosides $4 \mathrm{a}$ and $\mathbf{4 b}$ was carried out by reaction of $\mathbf{4 a}$ or $\mathbf{4 b}$ with methanolic sodium methoxide. Hence, sirring at room temperature at $24 \mathrm{~h}$ (TLC) yielded the corresponding free $N$-nucleoside $5 \mathrm{a}$ or $\mathbf{5 b}$, respectively (see Scheme 1 ). The ${ }^{1} \mathrm{H}$ NMR of $\mathbf{5 a}$ showed the expected base moiety protons in addition to the sugar moiety protons, however no signal for aromatic proton appeared. However, the trial to get fused pyrimidine nucleosides, namely pyrido[2,3- $d$ ]pyrimidine nucleosides $(7 \mathrm{a}, \mathrm{b})$ via the reaction of 
6-amino-2-thio and 2-methylthiouracil nucleosides $(4 \mathrm{a}, \mathrm{b})$ with benzylidene acetophenone (6) [29] in either ethanol or dimethylformamide according to the reported methods [30] [31]. Unfortunately it was failed (see Scheme 1).

Furthermore, 6-amino-1-benzyl-2-thiouracil nucleoside (10) was synthesized by reaction of 6-amino-1-benzyl-2-thiouracil (8)) [32] with 1- $O$-acety1-2,3-5-tri$O$-benzoyl- $\beta$-D-ribofuranose (3) to get the protected nucleoside 9 , followed by debenzoylation of 9 by stirring in methanolic sodium methoxide at room temperature (Scheme 2).

In addition the ribosylation of 5,6-dimethylthieno[2,3- $d$ ]pyrimidin-4-one (11a) and 5,6,7,8-tetrahydro-3H-benzo[4,5]thieno[2,3- $d$ ] pyrimidin-4-one (11b) [33] [34] were studied by the same manner to get1-(2,3,5-tri- $O$-benzoyl- $\beta$-Dribofuranosyl)-5,6-dimethylthieno[2,3- $d$ ]pyrimidin-4-one (12a) and1-(2,3,5-tri$O$-benzoyl- $\beta$-D-ribofuranosyl)-5,6,7,8-tetrahydro-3 $H$-benzo [4,5]thieno-[2,3- $d]$ pyrimidin-4-one (12b), respectively. Debenzoylation of each of $12 \mathrm{a}$ and $12 \mathrm{~b}$ in methanolic sodium methoxide at room temperature afforded 1-( $\beta$-D-ribofuranosyl)5,6-dimethylthieno[2,3- $d$ ] pyrimidin-4-one (13a) and 1-( $\beta$-D-ribofuranosyl)5,6,7,8-tetrahydro-3H-benzo[4,5] thieno[2,3- $d$ ] pyrimidin-4-one (13b) (Scheme 3).

\subsection{Antimicrobial Activity}

Ten products, namely, 4a,b; 5a,b; 9; 10; 13a,b and 14a,b were evaluated for their antibacterial and antifungal activities in vitro against gram negative bacteria [Escherichia coli (EC) and gram positive bacteria [Staphylococcus aureus (SA)] and against fungal, Aspergillus flavus (AF) and Candida albicans (CA). The antibacterial and antifungal activities were carried out in the Microbiology Division of Microanalytical Center of Cairo University, using the diffusion plate<smiles>Nc1cc(=O)[nH]c(=S)n1Cc1ccccc1</smiles>

8

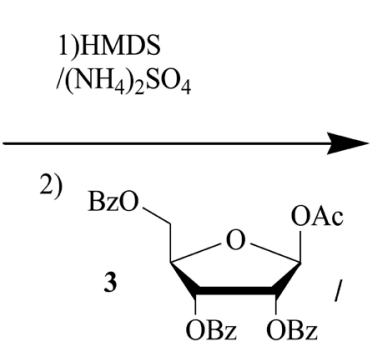

Triflate/ $(\mathrm{CH} 2)_{2} \mathrm{Cl}_{2}$

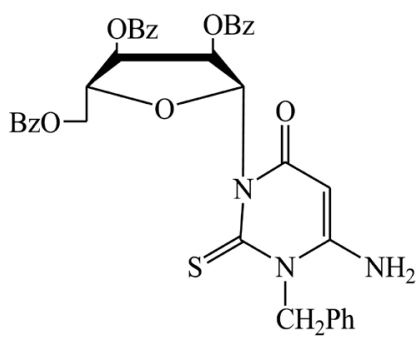

9<smiles>Nc1cc(=O)n(Cc2ccccc2)c(=S)n1COCCO</smiles>

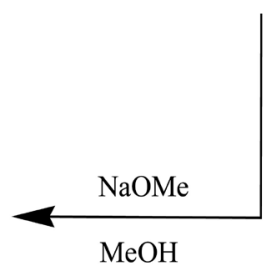

10

Scheme 2. Synthesis of 6-amino-1-benzyl-2-thiouracil nucleoside. 
<smiles>[R]c1sc(N)c(C(=O)[OH2+])c1[R]</smiles>

11 a,b
$\mathrm{HCONH}_{2}$

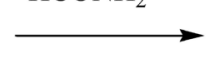

$\mathrm{NaOMe} / \mathrm{MeOH}$

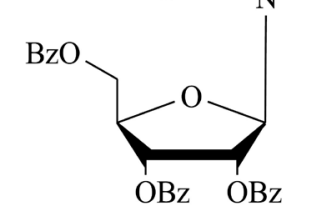

13 a,b<smiles>[R]c1sc2[nH]cnc(=O)c2c1[R]</smiles>

12 a,b
1) $\mathrm{HMDS} /$

$\left(\mathrm{NH}_{4}\right)_{2} \mathrm{SO}_{4}$

2)

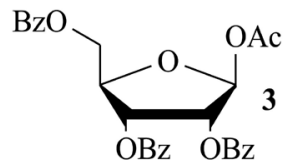

$\left(\mathrm{CH}_{2}\right)_{2} \mathrm{Cl}_{2} /$ triflate

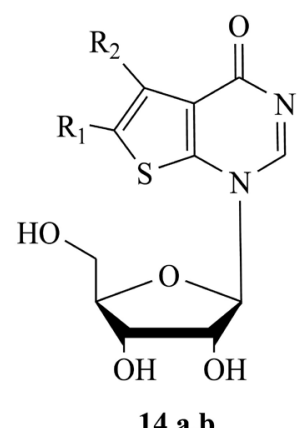

14 a,b

$$
\begin{aligned}
& \mathrm{a}, \mathrm{R} 1=\mathrm{R} 2=\mathrm{CH}_{3} \\
& \mathrm{~b}, \mathrm{R} 1=\mathrm{R} 2=
\end{aligned}
$$<smiles>C1CCCCC1</smiles>

Scheme 3. Synthesis of thieno[2,3-d]pyrimidin-4-one nucleosides.

method [35] [36], a bottomless cylinder containing a measured quantity (1 mI, $\mathrm{mg} / \mathrm{mL}$ ) of the sample is placed on ( $9 \mathrm{~cm}$ diameter) containing a solid bacterial medium (nutrient agar broth) or fungal medium (Dox's medium) which has been heavily seeded with the spore suspension of the test organism. After incubation ( $24 \mathrm{~h}$ for bacteria and 5 days for fungi), the diameter of the clear zone of inhibition surrounding the sample is taken as measure of the inhibitory power of the sample against the particular test organism. The reference antibiotics Ampicillin (antibacterial agent) and Amphotericin B (antifungal agent) were used as references to evaluate the potency of the tested compounds under the same condition. The test results are depicted in Table 1 on the following basis: The solvent used was dimethylsulfoxide and concentration of the sample in $100 \mu \mathrm{g} / \mathrm{ml}$.

The test results revealed that the compounds, $5 \mathrm{a}, \mathrm{b} ; 10 ; 13 \mathrm{~b}$ and $14 \mathrm{~b}$ exhibited moderate activity against the two bacteria species and all compounds except $14 \mathrm{~b}$ showed no activity against the two fungi species (Table 1).

\section{Conclusion}

In conclusion, new selective $N$-nucleosides and not $S$-nucleosides were synthesized by using silylation method in good yields. Such nucleosides were of 2-thio and 2-methylthiouracil and 1-benzyl-2-thiouracil as pyrimidine derivatives as 
Table 1. Antibacterial and antifungal activities of some of the synthesized compounds.

\begin{tabular}{|c|c|c|c|c|}
\hline Compound No. & $\begin{array}{l}\text { Escherichia coli } \\
\qquad \begin{array}{c}\text { (EC) } \\
\mathrm{G}^{-}\end{array}\end{array}$ & $\begin{array}{c}\text { Staphylococcus aureus } \\
\text { (SA) } \\
\mathrm{G}^{+}\end{array}$ & $\begin{array}{l}\text { Aspergillus flavus } \\
\text { (AF) } \\
\text { Fungus }\end{array}$ & $\begin{array}{c}\text { Candida albicans } \\
\text { (CA) } \\
\text { Fungus }\end{array}$ \\
\hline Control: DMSO & 0.0 & 0.0 & 0.0 & 0.0 \\
\hline $\begin{array}{c}\text { Ampicillin } \\
\text { Antibacterial agent }\end{array}$ & 22 & 18 & 0 & 0 \\
\hline $\begin{array}{l}\text { Amphotericin B } \\
\text { Antifungal agent }\end{array}$ & 0 & 0 & 17 & 19 \\
\hline $4 \mathrm{a}$ & 0.0 & 0.0 & 0.0 & 0.0 \\
\hline $4 \mathrm{~b}$ & 0.0 & 0.0 & 0.0 & 0.0 \\
\hline $5 \mathrm{a}$ & 10 & 10 & 0.0 & 0.0 \\
\hline $5 b$ & 11 & 10 & 0.0 & 0.0 \\
\hline 9 & 0.0 & 0.0 & 0.0 & 0.0 \\
\hline 10 & 9 & 9 & 0.0 & 0.0 \\
\hline $13 \mathrm{a}$ & 0.0 & 0.0 & 0.0 & 0.0 \\
\hline $13 \mathrm{~b}$ & 9 & 9 & 0.0 & 0.0 \\
\hline $14 \mathrm{a}$ & 0.0 & 0.0 & 0.0 & 0.0 \\
\hline $14 \mathrm{~b}$ & 10 & 10 & 11 & $\begin{array}{r}10 \\
1 I I I\end{array}$ \\
\hline
\end{tabular}

Inhibition Zone Diameter (IZD*) $\left(\mathrm{mm} / \mathrm{mg}\right.$ Compound Tested). ${ }^{*} \mathrm{IZD}=2-9 \mathrm{~mm}$ beyond control $=($ low activity). IZD $=10-20 \mathrm{~mm}$ beyond control $=$ (moderate activity). IZD $=20-30 \mathrm{~mm}$ beyond control $=$ (high activity).

well as 5,6-dimethyl-thieno[2,3-d]pyrimidin-4-one and 5,6,7,8-tetrahydro-3Hbenzo-[4,5]thieno-[2,3-d]pyrimidine-4-one as fused pyrimidine derivatives. The new nucleosides formed were structurally characterized and tested for biological activity against fungi and bacteria species. Some of the tested products showed moderate activity and the results were reported. Further exploration of the synthesis of $N$ and/or $S$-nucleosides and their investigations to get antiviral agents are currently under studying in our laboratory.

\section{Conflicts of Interest}

The authors declare no conflicts of interest regarding the publication of this paper.

\section{References}

[1] Pareek, A., Rani, P., Kumar, N., Sharma, P. and Kishore, D. (2013) The Role of Pyrimidines and Its Derivatives in Heterocyclic Chemistry. International Journal of Chemistry and Pharmaceutical Sciences, 4, 7-12.

[2] El-Sayed, W.A., Mohamed, A.M., Khalaf1, H.S., EL-Kady, D.S. and Al-Manawaty, M. (2017) Synthesis, Docking Studies and Anticancer Activity of New Substituted Pyrimidine and Triazolopyrimidine Glycosides. Journal of Applied Pharmaceutical Science, 7, 1-11. 
[3] Dinakaran, V.S., Bomma, B. and Srinivasan, K.K. (2012) Fused Pyrimidines, the Heterocycle of Diverse Biological and Pharmacological Significance. Der Pharma Chemica, 4, 255-265.

[4] MacCoss, M. and Robins, M.J. (1991) Anticancer Pyrimidines, Pyrimidine Nucleosides and Prodrugs. In: Wilman, D.E.V., Ed., The Chemistry of Antitumor Agents, Chapman and Hall, Springer, Dordrecht, 261-298.

https://doi.org/10.1007/978-94-009-0397-5_9

[5] Maurinsh, Y., Schraml, J., De Winter, H., Blaton, N., Peeters, O., Lescrinier, E., Rozenski, J., Van Aerschot, A., De Clercq, E., Busson, R. and Herdewijn, P. (1997) Synthesis and Conformational Study of 3-Hydroxy-4 (Hydroxymethyl)-1-Cyclohexanyl Purines and Pyrimidines. The Journal of Organic Chemistry, 62, 2861-2871. https://doi.org/10.1021/jo962204x

[6] Ostrowski, T., Wroblowski, B., Busson, R., Rozenski, J., De Clercq, E., Bennet, M.S., Champness, J.N., Summers, W.C., Sanderson, M.R. and Herdewijn, P. (1998) 5-Substituted Pyrimidines with a 1,5-Anhydro-2,3-Dideoxy-d-arabino-Hexitol Moiety at N-1: Synthesis, Antiviral Activity, Conformational Analysis, and Interaction with Viral Thymidine Kinase. Journal of Medicinal Chemistry, 41, 4343-4353. https://doi.org/10.1021/jm980287z

[7] Spanou, C., Manta, S., Komiotis, D., Dervishi, A. and Kouretas, D. (2007) Antioxidant Activity of a Series of Fluorinated Pyra No-Nucleoside Analogues of $\mathrm{N}^{4}$-Benzoyl Cytosine and $\mathrm{N}^{6}$-Benzoyl Adenine. International Journal of Molecular Sciences, 8, 695-704. https://doi.org/10.3390/i8070695

[8] Haouz, A., Vanheusden, V., Munier-Lechman, H., Froeyen, M., Herdewijn, P., Van Calenbergh, S. and Delarue, M. (2003) Enzymatic and Structural Analysis of Inhibitors Designed against Mycobacterium tuberculosis Thymidylate Kinase: New Insights into the Phosphoryl Transfer Mechanism. The Journal of Biological Chemistry, 278, 4963-4971. https://doi.org/10.1074/jbc.M209630200

[9] Vastmans, K., Froeyen, M., Kerremans, L., Pochet, S. and Herdewijn, P. (2001) Reverse Transcriptase Incorporation of 1,5-Anhydrohexitol Nucleotides. Nucleic Acids Research, 29, 3154-3163. https://doi.org/10.1093/nar/29.15.3154

[10] Elgemeie, G.H., Alkhursani, S.A. and Mohamed, R.A. (2019) New Synthetic Strategies for Acyclic and Cyclic Pyrimidinethione Nucleosides and Their Analogues. Nucleosides, Nucleotides and Nucleic Acids, 38, 12-87. https://doi.org/10.1080/15257770.2018.1498511

[11] Mosselhi, M.A.N., Break, L.M. and Aljaied, N.M.G. (2017) Nucleosides 9: Design and Synthesis of New 8-Nitro and 8-Amino-Xanthine Nucleosides of Expected Biological Activity. Nucleosides, Nucleotides \& Nucleic Acids, 36, 745-756. https://doi.org/10.1080/15257770.2017.1395036

[12] Mosselhi, M.A.N. and Neidlein, R. (2009) Nucleosides $5^{15}$ : Synthesis of Novel 1,2,4-Triazolo [3,4-c]-1,2,4-Triazole Nucleosides. Nucleosides, Nucleotides \& Nucleic Acids, 28, 1095-1103. https://doi.org/10.1080/15257770903368377

[13] Metwally, N.H., Abdalla, M.A., Mosselhi, M.A.N. and El-Desoky, E.A. (2010) Nucleosides 6, Synthesis and Antimicrobial Activity of Some New N-Glycosides of 2-Thioxo-4-Thiazolidinone Derivatives. Carbohydrate Research, 345, 1135-1141. https://doi.org/10.1016/j.carres.2010.04.011

[14] Mosselhi, M.A.N. and Break, L.M. (2011) Nucleosides 7: Synthesis, Structure and Biological Activity of New 6-Arylideneamino-2-thio and 2-BenzylthiopyrimidineN-Nucleosides. Nucleosides, Nucleotides \& Nucleic Acids, 30, 681-695.

[15] Break, L.M., Mosselhi, M.A.N. and Elshafai, N.M. (2013) Nucleosides [8]: Ribosyla- 
tion of Fused Quinazolines: Synthesis of New [1,2,4] Triazolo [5,1- $b]$ and $[1,2,4]$ Triazino $[3,2-b]$ Quinazoline Nucleosides of Fluorescence Interest. Journal of Chemistry, 2013, Article ID: 612756. https://doi.org/10.1155/2013/612756

[16] Mosselhi, M.A.N., Darwish, E. and Peseke, K. (2008) Synthesis and Antimicrobial Activity of New Imidazo- and Pyrimido[2,1-f]-Theophyllines. Monatshefte für Chemie-Chemical Monthly, 139, 825-834.

https://doi.org/10.1007/s00706-008-0854-Z

[17] Break, L.M., Shmiss, N.A.M.M. and Mosselhi, M.A.N. (2010) Nucleosides 4: Synthesis of Some New $S$-Nucleoside Derivatives of 2-Thioxo(2,4-Dithioxo)-5,6,7,8Tetrahydrobenzo-Thieno[2,3-d]Pyrimidin-4-(3H) Ones. Phosphorus, Sulfur \& Silicon and the Related Elements, 185, 1615-1622. https://doi.org/10.1080/10426500903147159

[18] Mosselhi, M.A.N. (1993) Nucleoside, I Ribosylation of 8-Substituted Theophylline Derivatives. Nucleosides and Nucleotides, 12, 431-439. https://doi.org/10.1080/07328319308021213

[19] Mosselhi, M.A.N. (1999) Nucleosides 2: Synthesis and Properties of 3,4-Diaryl-4,5Dihydro-1-( $\beta$-D-Ribofuranosyl)-1,2,4-Triazole-5-Thiones. Nucleosides and Nucleotides, 12, 2043-2049. https://doi.org/10.1080/07328319908044863

[20] Mosselhi, M.A.N. and Seliger, H. (2001) Nucleosides $3^{1}$ : Synthesis of Novel 1,3,4Oxadiazole Nucleosides. Journal of Chemical Research, 2001, 359-362. https://doi.org/10.3184/030823401103170278

[21] Johns, C.O. and Hendrix, B.M. (1915) Researchs on Purines xvi on the Isomeric Monomethyl Derivatives of 2-Methyl Mercap to-4-Amino-6-Oxypyrimidine on 1-Methyl-2-Methylmercapto-6-8-Dioxypurine. The Journal of Biological Chemistry, 20, 153-160. http://www.jbc.org/content/20/2/153.citation

[22] a) Taylor, E.C., Vogel, O. and Cheng, C.C. (1959) Studies in Purine Chemistry. II. A Facile Synthesis of 2-Substituted Adenines. The Journal of Organic Chemistry, 81, 2442-2448. https://doi.org/10.1021/ja01519a042

b) Youssif, S., El-Bahaie, S. and Nabih, E. (2003) A Facile One-Pot Synthesis of Fused 2-Thiouracils: Dipyrimidinopyridine, Pyrazolopyrimidine and Pyridazinopyrimidines. Bulletin of the Korean Chemical Society, 24, 1429-1432. https://doi.org/10.5012/bkcs.2003.24.10.1429

[23] a) Vorbrueggen, H. and Krolikiewicz, K. (1975) Neue Katalysatoren für die Nucleosidsynthese. Angewandte Chemie, 87, 417. https://doi.org/10.1002/ange.19750871110

b) Vorbrueggen, H., Krolikiewicz, K. and Bennua, B. (1981) Nucleoside Syntheses, XXII: Nucleoside Synthesis with Trimethylsilyl Triflate and Perchlorate as Catalysts. Chemische Berichte, 114, 1234-1255. https://doi.org/10.1002/cber.19811140404

[24] Kalinowski, H.O., Berger, S. and Braun, S. (1984) ${ }^{13}$ C NMR Spectroscopy. Georg Thieme Publisher, Stuttgart, Germany.

[25] Larsen, J.S., Abdel Aal, M.T. and Pedersen, E.B. (2001) Synthesis and Anti-HIV Activity of HEPT and S-DABO-Analogues with 5-Benzyl and 5-Phenyl Substituents. Journal of Heterocyclic Chemistry, 38, 679-683. https://doi.org/10.1002/jhet.5570380323

[26] Pakulski, Z., Pierozynski, D. and Zamojski, A. (1994) Reaction of Sugar Thiocyanates with Grignard Reagents. New Synthesis of Thioglycosides. Tetrahedron, 50, 2975-2992. https://doi.org/10.1016/S0040-4020(01)87009-5

[27] Shawali, A.S., Ali, N.A.H. and Osman, D.A. (2006) Synthesis and Biological Activity of New Functionalised Cyclohep Ta[4,5]-Thieno[2,3- $d][1,2,4]$ Triazolo[4,3-a]Pyrimidin- 
5-Ones. Journal of Chemical Research, 2006, 327-332.

https://doi.org/10.3184/030823406777411016

[28] Hassan, N.A. (2005) Novel Synthesis of $S$-Glycosides Derived from 5, 6-Disubstituted Thieno [2,3-d] Pyrimidin-4-One-2-Thiones. Journal of Sulfur Chemistry, 26, 343-352. https://doi.org/10.1080/17415990500456723

[29] Furness, B.S., Hannaford, A.J., Smith, P.W.G. and Tatchell, A.R. (1980) Vogel's Textbook of Practical Organic Chemistry. Longman, Essex, 796.

[30] Quiroga, J., Insuasty, B., Sanchez, A., Nogueras, M. and Meie, H. (1992) Synthesis of Pyrido[2,3-d]Pyrimidines in the Reaction of 6-Amino-2,3-Dihydro-2-Thioxo4(1H)-Pyrimidinone with Chalcones. Journal of Heterocyclic Chemistry, 29, 1045-1048. https://doi.org/10.1002/jhet.5570290502

[31] Abbas, H.A., Hafez, H.N., El-Gazzar, A.R. (2011) Synthesis, in Vitro Antimicrobial and in Vivo Antitumor Evaluation of Novel Pyrimidoquinolines and Its Nucleoside Derivatives. European Journal of Medicinal Chemistry, 46, 21-30. https://doi.org/10.1016/j.ejmech.2010.09.071

[32] Al-Masoudi, N. and Pfleiderer, W. (1993) Nucleosides LIII Syntheses and Reactions of 6,7-Dipyridyllumazine and 2'-Deoxylumazine N-1 Nucleosides. Pteridines, 4, 119-125. https://doi.org/10.1515/pteridines.1993.4.3.119

[33] Al-Taisan, K.M., Al-Hazimi, H.M.A. and Al-Shihry, S.S. (2010) Synthesis Characterization and Biological Studies of Some Novel Thieno[2,3-d]Pyrimidines. Molecules, 15, 3932-3957. https://doi.org/10.3390/molecules15063932

[34] Gewald, K., Schinke, E. and Böttcher, H. (1966) Heterocyclen aus CH-Aciden Nitrilen, VIII. 2-Amino-Thiophene aus Methylenaktiven Nitrilen, Carbonylverbindungen und Schwefel. Chemische Berichte, 99, 94-100. https://doi.org/10.1002/cber.19660990116

[35] Pfaller, M.A., Burmeister, L. and Bartlett, M.A. (1988) Rinaldi, Multicenter Evaluation of Four Methods of Yeast Inoulum Preparation. Journal of Clinical Microbiology, 26, 1437-1441.

[36] Matar, M.J., Ostrosky-Zeichner, L., Paetznick, V.L., Rodriguez, J.R., Chen, E. and Rex, J.H. (2003) Correlation between E-Test, Disk Diffusion and Microdilution Methods for Antifungal Susceptibility Testing of Fluconazole and Voriconazole. Antimicrobial Agents and Chemotherapy, 47, 1647-1651. https://doi.org/10.1128/AAC.47.5.1647-1651.2003 